\title{
PROBLEM PODMIOTOWOŚCI \\ PRAWNOMIĘDZYNARODOWEJ KSIĘSTWA SEALAND
}

\author{
Bartłomiej H. Toszek*
}

\author{
THE INTERNATIONAL SUBJECTIVITY PROBLEM \\ OF THE PRINCIPALITY OF SEALAND
}

\begin{abstract}
The Principality of Sealand was founded on the abandoned military platform on the North Sea. Because of its location beyond the British territorial waters, it was not the point of interest of the British authorities. In 1960 and 1970s, the Principality have got its national emblems and constitution. Despite of this initial development, most of the citizens moved from the platform to mainland because of hard conditions of life. The most dangerous threat for the Principality existence was the declaration of widening British territorial waters zone up to 12 NM (Nautical Miles), but no British troops or navy ship tried to disturb Sealand's sovereignty. Despite 'not disturbed' status, the Principality is not the state in the meaning of the international law. It has not got its territory nor people, because officially the platform is the Ministry of Defence property and all of Sealand's citizens live in the mainland now. The Principality has not been recognized by any state or international organization, so it has no possibilities to take part in international relations. From the legal point of view, the Principality is not only a state, but even quasi-state, however, it could be recognised in the future as a virtual micronation, although it is not a legal category.
\end{abstract}

\section{KEYWORDS}

international relations, international subjectivity, recognition of the state 'The Principality of Sealand, The United Kingdom

* Uniwersytet Szczeciński, Instytut Politologii i Europeistyki. 
W powszechnym mniemaniu pojęcie „państwa” stanowi oczywistą kategorię, która poprzez swoją obecność w codziennym życiu całego społeczeństwa może być z łatwością zdefiniowana przez każdego człowieka. Jednak w rzeczywistości nieostre definicje potoczne nie odpowiadają różnorodności istniejących we współczesnym świecie form państwowych ${ }^{1}$, których określenie wymaga precyzji właściwej dla języka prawnego. Problem ten dotyczy w szczególności tych quasi-państw, które nie zostały uznane przez ogół lub część społeczności międzynarodowej i w konsekwencji nie nawiązały stosunków zagranicznych, natomiast spełniają inne kryteria uzasadniające ich traktowanie jako organizmów państwowych. Wśród podmiotów tego rodzaju największe zainteresowanie opinii publicznej² skupia Księstwo Sealand, aspirujące do rangi suwerennego państwa od niemal 50 lat.

Twórcą Księstwa Sealand był emerytowany major armii brytyjskiej Roy „Paddy” Bates, który w październiku 1965 roku założył piracką rozgłośnię radiową Radio Essex na opuszczonej platformie przeciwlotniczej HM Fort Knock John znajdującej się u ujścia Tamizy. Ponieważ za nadawanie programów radiowych bez licencji na właściciela stacji została nałożona grzywna w wysokości 100 GBP, a wniosek o rejestrację Radio Essex został odrzucony, Bates zdecydował się przenieść swoją rozgłośnię na inną opuszczoną platformę przeciwlotniczą HM Fort Roughs $s^{3}$, usytuowaną na Morzu Północnym na szerokości geograficznej $51^{\circ} 53^{\prime} 40^{\prime \prime} \mathrm{N}$ i długości geograficznej $1^{\circ} 28^{\prime} 57^{\prime \prime} \mathrm{E}, \mathrm{tj}$. w odległości 7 mil morskich od wybrzeży Wielkiej Brytanii. Ponieważ szerokość pasa brytyjskich wód teryto-

${ }^{1}$ M. Sobczyński, Państwa i terytoria zależne. Ujęcie geograficzno-polityczne, Toruń 2006, s. 11.

2 Na stronach internetowych Księstwa Sealand nie zostały umieszczone liczniki rejestrujące liczbę odwiedzin, natomiast $\mathrm{z}$ danych znajdujących się na stronach internetowych Rządu Księstwa Sealand na Uchodźstwie wynika, że w okresie od 13 maja 2002 do 31 października 2004 r. strony te odwiedziło 2770945 internautów. Zob. Principality of Sealand, Webserver Statistics from May 13, 2002 - October 31, 2004, http:// http://principality-of - sealand.eu/statistic_e.html, odczyt z dn. 25.09.2012. Z kolei polską stronę internetową o Księstwie Sealand, uruchomioną 18 kwietnia 2008 r., obejrzało do dnia 11 lipca 2008 r. 22521 osób. Zob. Księstwo Sealand, Sealand Poland, Serwis, http://www.sealand.yoyo. pl/index.php?id=serwis, odczyt $\mathrm{z}$ dn. 11.07.2008.

3 Platforma HM Fort Roughs została skonstruowana na zlecenie Admiralicji Brytyjskiej przez Guya Ansona Maunsella, a następnie zatopiona w obecnym miejscu w lutym 1942 r. w celu zapewnienia ochrony portu Harwich przed niemieckimi atakami lotniczymi i rakietowymi. W okresie działań wojennych na platformie przebywał oddział Royal Navy, liczący od 150 do 300 osób. Ich liczba stopniowo malała po zakończeniu II wojny światowej, a ostatni żołnierze zostali wycofani w $1956 \mathrm{r}$. W tym samym roku Ministerstwo Obrony przekazało zarząd HM Fort Roughs korporacji Trinity House, zob. Project Redsand, History, http://www. project-redsand.com/ history.htm, odczyt z dn. 9.07.2014. 
rialnych wynosiła wówczas 3 mile morskie, nie ulegało wątpliwości, że platforma zajęta przez Batesa znajduje się na wodach międzynarodowych, niepodlegających jurysdykcji brytyjskiej ${ }^{4}$. Pomimo tego Radio Essex musiało zostać ostatecznie zlikwidowane ze względu na regulacje brytyjskiej ustawy z dnia 14 sierpnia 1967 roku skierowanej przeciwko pirackim rozgłośniom radiowym (Marine Broadcasting Offences Act 1967)5, która znajdowała zastosowanie do obywateli brytyjskich, bez względu na to, czy przebywali oni na terytorium Zjednoczonego Królestwa, czy poza nim. Chociaż Roy Bates został zmuszony do zaprzestania swojej dotychczasowej działalności, to jednak nie opuścił platformy HM Fort Roughs, lecz w dniu 2 września 1967 roku ogłosił ją suwerennym państwem pod nazwą Księstwa Sealand. Deklaracja nie wywołała początkowo żadnego oddźwięku ze strony władz brytyjskich, które nie widziały potrzeby zajmowania się ekscentrycznym dziwakiem roszczącym sobie pretensje do brudnej, rdzewiejącej platformy na Morzu Północnym ${ }^{6}$ o powierzchni $560 \mathrm{~m}^{2}$ i otaczających ją wód morskich o powierzchni $4000 \mathrm{~m}^{2}$. Świadomość takiego stanu rzeczy miał także Bates, który w wywiadzie umieszczonym na stronie internetowej swojego quasi-państwa (Sealand News) stwierdził: „realizacja moich ambicji trwała bardzo długo [...], a na początku nikt nie traktował mnie poważnie"?. Sytuacja uległa zmianie w maju 1968 roku, kiedy zarządzająca HM Fort Roughs korporacja Trinity House wysłała na platformę dwóch pracowników, którzy mieli przeprowadzić prace konserwatorskie. Nie zostali oni jednak wpuszczeni na platformę, a „książę” i jego 16-letni syn Michael zagrozili im użyciem broni w przypadku ponownego przybycia. W odpowiedzi, kiedy Roy Bates udał się na stały ląd, został aresztowany przez funkcjonariuszy policji za posiadanie broni palnej bez zezwolenia. Ostatecznie wyrokiem z dnia 25 października 1968 roku sąd hrabstwa Essex (Essex Assizes) w Chelmsford oddalił zarzuty wysunięte

${ }^{4}$ Pomimo przystąpienia do Konwencji ONZ o morzu terytorialnym i strefie przyległej z 29 kwietnia 1958 r., zezwalającej sygnatariuszom na rozciągnięcie swoich przepisów celnych, skarbowych, imigracyjnych i sanitarnych na pas wód przybrzeżnych o szerokości 12 mil morskich, Wielka Brytania nie korzystała z tej możliwości aż do 1 października 1987 roku, tj. do chwili rozszerzenia pasa wód terytorialnych.

${ }^{5}$ Ustawa została uchwalona w wykonaniu postanowień Traktatu Rady Europy z 22 stycznia 1965 r. w sprawie zwalczania piractwa radiowego. Zob. Council of Europe, European Agreement for the Prevention of Broadcasts transmitted from Stations outsider National Territories, http://conventions.coe. int/Treaty/en/Treaties/ Html/053.htm, odczyt z dn. 9.07.2014.

${ }^{6}$ Sealandia - milion euro za metr, http://www.money.pl/gospodarka/wiadomości/artykul/sealandia;-;m Ilion;euro;za;metr,110,0,214126.html, odczyt z dn. 9.07.2014.

7 The Royal Family, http://www.sealandnews.com/the-royal-family, odczyt z dn. 9.07.2014. 
wobec Roya i Michaela Batesów, wskazując, że „sądy angielskie mogą rozstrzygać o ukaraniu jedynie za czyny popełnione [...] na terytorium Wielkiej Brytanii oraz należących do niej wyspach i obszarze wód terytorialnych wewnątrz pasa o szerokości 3 mil [...], a także statkach poruszających się pod flagą brytyjską [...], a do żadnej z tych kategorii nie należy wieża Roughs"8. Wprawdzie w wyroku z 1968 roku zostały jedynie określone przeszkody formalnoprawne uniemożliwiające sądowi merytoryczne rozpatrzenie sprawy, jednakże Roy Bates uznał je za potwierdzenie swoich roszczeń wobec HM Fort Roughs, opierających się na obowiązującej w prawie międzynarodowym publicznym zasadzie res nullis credit primo occupanti $i^{9}$. Wyrazem tego przekonania było wezwanie jednostek Royal Navy, uczestniczących w ćwiczeniach prowadzonych u wybrzeży południowo-wschodniej Anglii pod koniec 1968 roku, do niewpływania na obszar ogłoszony sealandzkimi wodami terytorialnymi w deklaracji z dnia 2 września 1967 roku: „W obronie suwerenności swojego państwa książę Roy nakazał okrętom marynarki wojennej wycofanie się. Zostały oddane strzały ostrzegawcze"10.

W latach siedemdziesiątych Księstwo Sealand zamieszkiwała 5-osobowa rodzina Batesów ${ }^{11}$ oraz „rozrastająca się stopniowo pionierska grupa [...] osadników"12, w skład której wchodzili przede wszystkim hippisi, żądni przygód awanturnicy i bezrobotni, ale także kilku prawników i przedsiębiorców. Jednak trudne warunki bytowe utrzymujące się na HM Fort Roughs, pomimo składanych przez Batesa deklaracji o przekształceniu platformy w „luksusowy pałac dla jego rodziny i bliskich”"13, przyczyniły się przed końcem dekady do powrotu na stały ląd znacznej części mieszkańców. „Klimat Sealandii był zabójczy. Jeden po drugim znikali znajomi, którzy kiedyś postanowili się tu osiedlić. Wilgoć, wiatr, zimno"14. W kolejnych latach liczba ludności Księstwa nie ulegała poważniejszym zmianom pozostając na poziomie 25-30 osób. Z treści raportu

8 Transcript of 1968 Court Decision, http://www.seanhastings.com/havenco/sealand/judgement. html, odczyt z dn. 9.07.2014.

9 Res nullis credit primo occupanti (łac.) rzecz niczyja przypada temu, kto pierwszy ją zawłaszczył.

${ }^{10}$ History of Sealand, http://www.sealandgov.org/history.html, odczyt z dn. 09.07.2014.

11 Do końca lat siedemdziesiątych Księstwo zamieszkiwała cała rodzina Batesów, tj. Roy „Paddy” z żoną Joan, synem Michaelem i córką Penelope „Penny”.

12 Principality of Sealand, http://www.muu.fi/amorph03/downloads/pdfs/principality_of _ sealand.pdf, odczyt z dn. 9.07.2014.

13 The Royal..., op. cit.

14 L.L. Talko, Sealandia. Królestwo za koniak, „Gazeta Wyborcza”, 5.12.2003., dodatek „Duży Format", s. 3. 
opublikowanego przez „władze” sealandzkie w Internecie wynika, że w 2002 roku platformę zamieszkiwało 27 osób, w tym 9\% w wieku do 14 roku życia, 82\% w wieku 15-64 lat i 9\% w wieku powyżej 64 roku życia. Zjawiska braku przyrostu naturalnego oraz emigracji, obejmującej $28 \%$ populacji (w latach 2000-2002), wynikały przede wszystkim z niekorzystnej struktury płci wyrażającej się stosunkiem kobiet do mężczyzn jak 1:4,4. Równocześnie jednak społeczność Księstwa była spójna pod względem etnicznym i kulturowym (wywodząc się w większości z Wielkiej Brytanii) oraz religijnym (26\% anglikanów oraz $74 \%$ wyznawców innych odłamów chrześcijaństwa ${ }^{15}$. Głównym źródłem dochodów społeczności sealandzkiej były początkowo wpływy ze sprzedaży miejscowych znaczków pocztowych emitowanych od 1969 roku oraz monet (o nominałach $1 / 4,1 / 2$ i 1 dolara sealandzkiego) wypuszczanych na rynek numizmatyczny od $1972 \mathrm{roku}^{16}$. Dodatkowe dochody zapewniały opłaty pobierane za wydanie wiz wjazdowych, usługi turystyczne dla osób zwiedzających HM Fort Roughs oraz wydawanie paszportów ${ }^{17}$ dokumentujących „obywatelstwo” sealandzkie. Uzyskiwane w ten sposób środki były jednak niewystarczające do pokrycia wydatków związanych z konserwacją platformy i zaspokojeniem potrzeb bytowych jej mieszkańców. W konsekwencji największą część budżetu Księstwa stanowiły bezzwrotne pożyczki udzielane przez prywatne przedsiębiorstwo rybackie należące do Michaela Batesa. Sytuacja uległa zasadniczej zmianie w maju 2000 roku, po nawiązaniu współpracy z amerykańską firmą HavenCo, polegającej na ustawieniu na platformie serwerów komputerowych służących do stworzenia „najbezpieczniejszej bazy danych [...] niepodlegającej kontroli rządowej”"18. Umowa pomiędzy Royem Batesem i reprezentującym HavenCo Seanem Hastingsem zagwarantowała Księstwu Sealand stałe dochody w wysokości przewyższającej ogólną sumę wydatków przeznaczonych na potrzeby „państwa” i jego mieszkańców. Już w 2002 roku wpływy budżetowe przewyższały wydatki

15 Principality of Sealand, op. cit.

16 Zob. Sealand (Principality of), http://www.imperial-collection.net/sealand03. html, odczyt z dn. 9.07.2014.

17 Roy Bates od początku istnienia Księstwa Sealand wydał ok. 300 paszportów, które są rzeczywiście używane przez ich posiadaczy przy przekraczaniu granic państwowych. Ponadto od końca lat osiemdziesiątych do 2000 r. ok. 150000 paszportów sealandzkich zostało wydrukowanych w Hiszpanii przez Federico Trujillo Ruiza, który ogłosił się księciem regentem Sealand. Paszporty te były rozprowadzane m.in. wśród mieszkańców Hongkongu pragnących uniknąć konieczności przyjęcia obywatelstwa chińskiego (po ok. 1000 USD za sztukę), a także wśród członków mafii działających m.in. w krajach bałkańskich i Rosji. Zob. szerzej: History of Sealand, op.cit.

18 Havenco-Data Centre Services, http://www.havenco.com/index.html, odczyt z dn. 9.07.2014. 
o 178000 USD $^{19}$, co pozwoliło Księstwu na uniezależnienie się od pomocy podmiotów zewnętrznych i realizację inwestycji finansowych na stałym lądzie. Pomimo tego „władze” sealandzkie nie zrezygnowały z wykorzystywania innych źródeł dochodów, prowadząc na swoich stronach internetowych sprzedaż filmów DVD i VCD, pocztówek, koszulek, kubków i żetonów z wizerunkiem HM Fort Roughs, stalowych śrub pochodzących ze zdemontowanych części platformy, a nawet sealandzkich tytułów szlacheckich ${ }^{20}$.

Decyzja o utworzeniu suwerennego państwa skłoniła Roya Batesa do zaprojektowania flagi i godła, jako atrybutów mających wskazywać na odrębność tego terytorium od Wielkiej Brytanii. Czarno-biało-czerwona flaga sealandzka, symbolizująca piracką działalność założycieli Księstwa, czystość ich intencji oraz królewską godność, została po raz pierwszy użyta w 1967 roku, a godło $\mathrm{z}$ maksymą E Mare Libertas ${ }^{21}$ zaczęło być stosowane po ogłoszeniu wyroku Essex Assizes w październiku 1968 roku. W kolejnej dekadzie powstała muzyka do hymnu sealandzkiego (wykonywanego bez słów), którą na zamówienie Batesa napisał znany angielski kompozytor Basil Simonenko. Natomiast 25 września 1975 roku została ogłoszona konstytucja Księstwa, opracowana przez niemieckiego prawnika prof. Alexandra G. Achenbacha (pełniącego dożywotnio funkcję premiera sealandzkiego).

Konstytucja z 1975 roku w preambule (dodanej w maju 1976 roku) stanowi, że Księstwo jest suwerennym podmiotem posiadającym zdolność nawiązywania i kształtowania stosunków międzynarodowych ${ }^{22}$. We wstępnej części tego aktu określone zostały wolności i prawa „obywatelskie”, do których zaliczono w całości postanowienia Powszechnej Deklaracji Praw Człowieka z 1948 roku $^{23}$ oraz wynikające wprost z Konstytucji prawa nieskrępowanego rozwoju osobistego we wszelkich sferach życia, wyboru zawodu, poruszania się i wyboru miejsca zamieszkania w obrębie Księstwa, równego traktowania wobec prawa, ochrony przyrodzonej godności ludzkiej, ochrony prawnej

19 Principality of Sealand, op.cit.

20 Zob. Church \& East Ltd. Souvenirs Shop, http://www.churchandeast.co.uk/shop/index.html, odczyt z dn. 9.07.2014.; Red Save. Become a Lord, Lady, Baron or Baroness, http://www.redsave.com/ index.asp? page Type=3\&pid=2091\&catId=21\&track=SealandShopLink, odczyt z dn. 9.07.2014.

21 E mare libertas lub E mari libertas (łac.) - z morza wolność.

22 Constitution of 1975, Preliminary Remark, http://principality-of-sealand.eu/pdf/c onstitutions. pdf, odczyt z dn. 9.07.2014.

${ }^{23}$ Zob. E.J. Osmańczyk, Encyklopedia ONZ i stosunków międzynarodowych, Warszawa 1986, s. $117-118$. 
gwarantowanej przez państwo, ochrony własności prywatnej, przedstawiania swoich spraw do rozstrzygnięcia niezawisłym sądom oraz prawa wynikające z zakazu ekstradycji i zakazu wymierzenia kary pozbawienia wolności bez prawomocnego wyroku sądowego ${ }^{24}$. Przepisy ustawy zasadniczej Księstwa przyznają szczególną pozycję dziedzicznemu „monarsze”, który posiada pełnię władzy ustawodawczej i wykonawczej, a nawet sądowniczej w zakresie egzekucji podatków, opłat administracyjnych, ceł oraz przestrzegania monopolu państwowego na określone rodzaje działalności produkcyjnej i usługowej ${ }^{25}$. Do jego kompetencji należy powoływanie „rządu”, w którego skład wchodzą szefowie resortów spraw zagranicznych; sprawiedliwości; gospodarki i finansów; spraw wewnętrznych i rozwoju; ruchu wewnętrznego, transportu, poczty i dziedzictwa kulturowego; specjalny minister ds. wewnętrznych i międzynarodowych oraz inni ministrowie powoływani doraźnie przez monarchę $\mathrm{w}$ razie potrzeby ${ }^{26}$. Konstytucja określa także organizację i zasady funkcjonowania „organów” wymiaru sprawiedliwości, tj. Najwyższego Sądu Sprawiedliwości oraz Sądu Apelacyjnego, wchodzących w skład Trybunału i orzekających na podstawie brytyjskiego common law w sprawach cywilnych i karnych oraz brytyjskiego prawa stanowionego w sprawach z zakresu prawa handlowego ${ }^{27}$. Postanowienia ustawy zasadniczej obejmują również regulacje dotyczące barw flagi sealandzkiej, języka urzędowego oraz waluty narodoweje' ${ }^{28}$ Oprócz Konstytucji z 1975 roku na system prawny Księstwa składają się akty rangi ustawowej, tj. Prawo podatkowe, Prawo o banku państwowym Księstwa Sealand, Prawo o rejestrze osobowym, handlowym i morskim, Prawo paszportowe i wizowe, Prawo konsularne oraz ustawa określająca zasady przyznawania Orderu Sealandzkiego, które zostały wydane en bloc 17 maja 1976 roku $^{29}$.

$\mathrm{Na}$ początku sierpnia 1978 roku grupa niemieckich i holenderskich przedsiębiorców zwróciła się do Roya i Joan Batesów z propozycją nawiązania współpracy gospodarczej. Po przybyciu „pary książęcej” do Wiednia okazało się jednak, że zaplanowane spotkanie zostało przesunięte na późniejszy termin.

${ }^{24}$ Constitution..., op. cit., $\$ 1-3,7-9$ i 19.

25 Ibidem, $\$ 4.2, \S 12.1$ i 5 .

26 Ibidem, $\$ 21.2$.

27 Ibidem, $\$ 12.4$.

28 Ibidem, $\$ 14,15$ i 20.3 .

29 Zob. Ibidem, Tax Law, Law concerning the State Bank of the Principality of Sealand, Law relating to the keeping in the field of powers of Attorney, Registration of companies and shipping, Law relating to passports and visas, Consular Law, Law referring to the Award of the Order of Sealand. 
Równocześnie Batesowie uzyskali „od znajomego rybaka [...] wiadomość, że ten widział helikopter transportowy kierujący się w stronę księstwa"30. Okazało się, że kierowany przez premiera Achenbacha rząd sealandzki - za pomocą uzbrojonych najemników holenderskich pod dowództwem Paula Trevisana - dokonał przewrotu na HM Fort Roughs, aresztując, a następnie deportując „następcę tronu” oraz osoby deklarujące wierność rodzinie założyciela Księstwa. Kilka dni później Roy i Michael Batesowie wraz z kilkoma przyjaciółmi wynajęli helikopter i zaatakowali platformę, którą udało im się odzyskać bez walki, dzięki kompletnemu zaskoczeniu przeciwników ${ }^{31}$. Po stłumieniu rebelii wszystkich jej uczestników nieposiadających „obywatelstwa” sealandzkiego wywieziono do Holandii, a przebywający w Niemczech przywódca buntu został zaocznie skazany za zdradę stanu na karę grzywny w wysokości 75000 DM². Natomiast Gernot Putz, który jako jedyny spośród rebeliantów posiadał wyłącznie „obywatelstwo” Księstwa, został skazany na karę ciężkich robót, tj. szlifowanie barierek platformy. „Sprawa [Putza] wywołała interwencje rządów Holandii i Niemiec do władz brytyjskich, które jednak uchyliły się od odpowiedzialności, powołując się na wyrok wydany przez sąd w 1968 r. Nie przyniosły efektu również [...] negocjacje osobiście prowadzone z Royem Batesem przez przedstawiciela ambasady niemieckiej w Londynie" ${ }^{33}$, toteż ostatecznie więzień został uwolniony dopiero po 7 tygodniach. Natomiast sama wizyta pracownika wydziału konsularnego ambasady Niemiec na HM Fort Roughs została potraktowana przez „władze” sealandzkie jako wyraz de facto uznania istnienia Księstwa przez RFN, chociaż „rząd niemiecki nigdy nie potwierdził tej interpretacji”" ${ }^{34}$.

Konsekwencją rebelii było utworzenie emigracyjnego Rządu Księstwa Sealand w Niemczech ${ }^{35}$ pod kierownictwem Alexandra Achenbacha oraz holenderskiego prawnika doktora Adriana L. Domena, któremu powierzono funkcję „księcia”. W sierpniu 1989 roku na czele Rządu na Uchodźstwie stanął Johannes Sieger, co wiązało się z przyjęciem nowej konstytucji oraz reorganizacją powiązań między

${ }^{30}$ L.L. Talko, op.cit., s. 5.

31 J. Ryan, G. Dunford, S. Sellars, Micronations, London 2006, s. 11.

32 Attempt to Free Captive from Private 'Island' Fails, „The Times”, 5.09.1978, s. 3.

33 J. Ryan, G. Dunford, S. Sellars, op. cit., s. 11.

34 Podatkowe raje: Sealandia, http://nczas.com/Europa/podatkowe-raje-sealandia, odczyt z dn. 9.07.2014.

35 Siedzibą Rządu Księstwa Sealand na Uchodźstwie jest miejscowość Rheda-Wiedenbrück, położona w północnej części kraju związkowego Nadrenia-Westfalia. 
poszczególnymi organami „władzy” Księstwa ${ }^{36}$. Z inicjatywy Siegera została założona spółka Sealand Trade Corporation, zajmująca się m.in. handlem maszynami i urządzeniami technicznymi pochodzącymi z demobilu po wycofaniu wojsk radzieckich z NRD w 1991 roku, poszukiwaniem Bursztynowej Komnaty ${ }^{37}$ oraz alternatywnych źródeł energii ${ }^{38}$. Naśladując działania prowadzone przez Roya Batesa, „władze” emigracyjne na początku lat dziewięćdziesiątych zamówiły srebrne dolary sealandzkie z wizerunkiem premiera Siegera, które zostały następnie wprowadzone na rynek numizmatyczny. Chociaż wszystkie te przedsięwzięcia były podejmowane w imieniu Księstwa, to jednak rodzina Batesów, wychodząc z założenia, że „nie jest to sprawa leżąca w gestii Sealandii [...], nigdy nie zaprotestowała przeciwko rządowi [...] na wychodźstwie" ${ }^{39}$.

W okresie od listopada 1968 roku do września 1987 roku władze brytyjskie nie podejmowały żadnych działań ukierunkowanych na przywrócenie kontroli nad HM Fort Roughs, co nie oznaczało jednak faktycznego uznania istniejącego na platformie quasi-państwa. Stanowisko w tej sprawie zostało wyraźnie określone przez Home Office ${ }^{40} \mathrm{w}$ treści skierowanego do obywatela niemieckiego Hansa Fuhra ${ }^{41}$ pisma nr MSC/78.574/9/3 z dnia 8 lipca 1981 roku, w którym stwierdzono, że chociaż HM Fort Roughs nie leży na obszarze Wielkiej Brytanii ani jej wód terytorialnych, to jednak „rządowi Zjednoczonego Królestwa nie jest znany jakikolwiek powód uzasadniający uznanie Fortu za państwo; Rząd nie ma również podstaw, aby sądzić, że powody takie mogłyby być znane jakiemukol-

36 Zob. Chronology of the Principality of Sealand, http://principality-of-seal and.eu/chronologie/ chrono_e.html, odczyt z dn. 9.07.2014.

37 Bursztynowa Komnata to kompletny wystrój apartamentu królewskiego, wykonany w latach 1701-1709 przez duńskiego mistrza bursztyniarskiego Gottfrieda Wolframa oraz niemieckiego rzeźbiarza Andreasa Schlütera na zamówienie króla pruskiego Fryderyka I Hohenzollerna. Do 1716 r. Komnata stanowiła część wyposażenia berlińskiego pałacu Charlottenburg, a następnie została podarowana carowi rosyjskiemu Piotrowi I Wielkiemu i przewieziona do Sankt Petersburga. Po wielokrotnych przeróbkach jej powierzchnia miała $55 \mathrm{~m}^{2}$, a łączna waga wszystkich elementów wynosiła ok. 6 ton. W okresie II wojny światowej dostała się w ręce Niemców i została wywieziona do zamku królewieckiego, gdzie była przechowywana do 1944 r. Pomimo wielu spekulacji dalsze losy Bursztynowej Komnaty pozostają nieznane. Zob. L. Adamczewski, Zaginiona komnata, Poznań 1993.

38 Zob. Chronology..., op.cit.

${ }^{39}$ L.L. Talko, op.cit., s. 6.

40 Home Office to ministerstwo spraw wewnętrznych Wielkiej Brytanii.

${ }^{41}$ W 1981 r. Hans Fuhr pełnił obowiązki ministra ds. morskich w Rządzie Księstwa Sealand na Uchodźstwie. 
wiek innemu rządowi” ${ }^{42}$. Konsekwencją ignorowania „problemu sealandzkiego” przez władze brytyjskie było również powstrzymanie się od podjęcia jakichkolwiek działań, które mogłyby położyć kres istnieniu Księstwa. Sytuacja ta nie zmieniła się nawet wówczas, gdy rząd Margaret Thatcher ${ }^{43}$ postanowił rozszerzyć dotychczasową 3-milową strefę brytyjskich wód terytorialnych do $12 \mathrm{mil}$ morskich (w obrębie których znalazła się platforma HM Fort Roughs) od dnia 1 października 1987 roku. W przededniu wejścia w życie tego postanowienia Roy Bates dokonał analogicznego rozszerzenia sealandzkich „wód terytorialnych”, wychodząc z założenia, że „nawet w przypadku gdyby żaden traktat brytyjsko-sealandzki nie uregulował zasad podziału spornych akwenów, to jednak w oparciu o ogólne reguły prawa międzynarodowego możliwe byłoby wytyczenie punktów znajdujących się w równej odległości od brzegów obu państw, wyznaczających przebieg granicy morskiej. [...] Ponadto w ten sposób brytyjskie wody terytorialne nie zablokują [Księstwu] dostępu do morza otwartego" ${ }^{44}$. Pozorny konflikt interesów Wielkiej Brytanii i społeczności zamieszkującej HM Fort Roughs nie wzbudził większego zainteresowania władz brytyjskich, ponieważ rodzina Batesów nie podjęła żadnych kroków zmierzających do rozciągnięcia swojego zwierzchnictwa nad obszarem uznanym w treści deklaracji z dnia 30 września 1987 roku za sealandzkie „wody terytorialne”. Równocześnie jednak „władze” sealandzkie były zdecydowane użyć wszelkich środków do obrony samej platformy, o czym świadczył incydent z 24 lutego 1990 roku polegający na oddaniu strzałów ostrzegawczych w kierunku statku pomocniczego RMAS ${ }^{45}$ Golden Eye. „Zgodnie z relacją majora Batesa [...] strzały Sealandczyków miały tylko uświadomić załodze statku, że znajduje się zbyt blisko filarów platformy. [...] Natomiast kapitan Golden Eye uznał, że statek jest rzeczywiście atakowany i wezwał na pomoc jednostki straży przybrzeżnej”46. Ostatecznie jednak incy-

${ }^{42}$ Letter of P. Ransford, Home Office to Hans Fuhr of July 8, 1981, http://principality-of - sealand. eu/pdf/roughs_tower.pdf, odczyt $\mathrm{z}$ dn.9.07.2014.

43 Margaret Hilda Thatcher była politykiem konserwatywnym, pełniła funkcję parlamentarnego sekretarza stanu w ministerstwie pomocy społecznej w latach 1961-1964 oraz ministra edukacji i nauki w latach 1970-1974; była premierem Wielkiej Brytanii w latach 1979-1990.

${ }^{44}$ History of Sealand, op.cit.

45 Królewska Morska Służba Pomocnicza (Royal Maritime Auxiliary Service, RMAS) powstała w 1974 r. jako cywilna agencja rządowa świadcząca usługi na rzecz marynarki wojennej. Zob. szerzej: Royal Fleet Auxiliary, http://www.royal-navy.mod.uk/server/show/conWebDoc.64/changeNav/3533, odczyt z dn. 9.07.2014.

${ }^{46}$ J. Cusick, Shots Fired in Sealand's Defence of a Small Freedom, „The Independent”, 24.02.1990, s. 6 . 
dent nie wywołał żadnych następstw politycznych, a śledztwo prowadzone w tej sprawie przez policję hrabstwa Suffolk zostało umorzone.

Na początku lat dziewięćdziesiątych Joan Bates wyprowadziła się z HM Fort Roughs ze względów zdrowotnych i zamieszkała początkowo na południowo-wschodnim wybrzeżu Anglii, a następnie przeniosła się wraz z mężem do Costa del Sol w Hiszpanii. Od tego czasu sprawami Księstwa zajmuje się formalnie „książę regent” Michael Bates, który jednak w rzeczywistości mieszka wraz ze swoją rodziną w Leigh-on-Sea w północnej Anglii ${ }^{47}$. Pozostali „obywatele” sealandzcy również stopniowo emigrowali na stały ląd, chociaż większość z nich nadal oficjalnie uważa się za mieszkańców platformy. Trudne warunki bytowe nie stanowiły natomiast przeszkody w wykorzystywaniu HM Fort Roughs do celów gospodarczych, z których największe znaczenie miało uruchomienie serwerów HavenCo w 2000 roku. Nieuregulowany status prawny Księstwa umożliwił powstanie na platformie oficjalnej strony internetowej rządu tybetańskiego na uchodźstwie Tibet Online ${ }^{48}$. „Książę Roy sam zaprosił Tybetańczyków i zaoferował darmowe usługi. [...] Gdyby Tybetańczycy zainstalowali się gdziekolwiek indziej [...], Chińczycy zaczęliby naciskać na zlikwidowanie domeny. A tak wszyscy rozkładają ręce. No tak, Tybetańczycy nadają z Sealandii, ale przecież Sealandia to niepodległe państwo. Cóż możemy zrobić? Z Sealandii mogliby nadawać na przykład ludzie walczący z potężnymi organizacjami. Może antyglobaliści, pragnący zaszkodzić wielkim korporacjom, ale obawiający się ich wpływów i pozwów sądowych, może Zieloni albo przeciwnicy Kościoła scjentologicznego. Każdy mógłby bez obaw o proces umieścić listę lekarzy konowałów, czarną listę dłużników albo skandaliczne szczegóły życia arystokratów. Żaden sąd nie może zablokować tych informacji. Nie wejdzie policja” ${ }^{\text {"99 }}$. Te same przyczyny, dla których obecnie Księstwo jest przedmiotem zainteresowania internautów, mogą w przyszłości stanowić istotny argument dla przedsiębiorców poszukujących możliwości zarejestrowania swoich firm w tzw. rajach podatkowych. W wywiadzie udzielonym polskiemu dziennikarzowi w 2003 roku Michael Bates jednoznacznie określił swój stosunek do możliwości wykorzystania HM Fort Roughs jako „biznes” ${ }^{50}$. Potwierdziły to kolejne kroki podjęte przez „księcia regenta”, który pod koniec 2006 roku, wbrew postanowieniom konstytucji Księstwa, zlecił

\footnotetext{
47 The Royal..., op.cit.

48 Zob. About Tibet Online, http://www.tibet.org/tibet.org, odczyt z dn. 25.09.2012.

${ }^{49}$ L.L. Talko, op.cit., s. 6.

50 Ibidem, s. 7.
} 
brytyjskiej firmie zajmującej się pośrednictwem w obrocie nieruchomościami sprzedaż praw do platformy za kwotę $750 \mathrm{mln}$ euro ${ }^{51}$. Równocześnie „władze” sealandzkie podjęły indywidualne negocjacje w sprawie sprzedaży praw do platformy z przedstawicielami serwisu internetowego The Pirate Bay. „Szwedzi, którzy prowadzą stronę thepiratebay.org [...], od razu poprosili swych sympatyków o zrzutkę" 52 , jednakże nie udało im się zgromadzić koniecznej kwoty i rozmowy zostały przerwane. Według informacji podanych przez Sealand News 16 września 2008 roku kolejne negocjacje miały być prowadzone z amerykańską firmą z branży internetowej Google Incorporation, „o ile rzeczywiście zamierza ona [...] budować globalną sieć internetową [...] pozostającą poza kontrolą rządową" ${ }^{33}$. Informacja ta wydawała się jednak wysoce wątpliwa zarówno dlatego, że domniemany kontrahent nie potwierdził jej w jakikolwiek sposób, ale również z uwagi na renomę Google Inc., której dotychczasowa działalność wskazywała, że nie obawia się funkcjonowania w ramach ograniczeń rynkowych narzucanych przez poszczególne państwa. Podobny charakter miały doniesienia umieszczone na australijskim portalu news.com.au dotyczące przeniesienia na terytorium Księstwa serwerów witryny internetowej WikiLeaks przez tajski koncern prasowy The Sunshine Press Co. Ltd. ${ }^{54}$ Pogłoski te stanowiły najprawdopodobniej element kampanii marketingowej, mającej doprowadzić do sprzedaży HM Fort Roughs przez rodzinę Batesów na jak najlepszych warunkach finansowych. Być może główną przyczyną zamiaru zbycia platformy był pożar spowodowany awarią generatora prądu 23 czerwca 2006 roku. Zniszczone zostało wówczas całe wyposażenie pomieszczeń mieszkalnych i biurowych, a także urządzenia umożliwiające zaspokajanie mieszkańcom Księstwa podstawowych potrzeb. W wyniku akcji ratunkowej przeprowadzonej przy użyciu helikoptera wojskowego oraz łodzi ratownictwa morskiego z Harwich udało się ewakuować obecnych na platformie mieszkańców i ugasić płomienie. Natomiast ponowna

51 Zob. Tiny North Sea Tax Heaven for Sale, http://www.abc.net.au/news/newsitems/2 00701/ s1823039.htm, odczyt z dn. 9.07.2014; Najmniejsze państwo świata na sprzedaż, http:// www.dziennik. pl/swiat/article18229/Najmniejsze_panstwo_swiata_na_sprzedaz.html, odczyt z dn. 9.07.2014.

52 Piraci chca mieć własne państwo, http://www.dziennik.pl/swiat/article17208/Piraci_chca_miec _wlasne_panstwo.html, odczyt z dn. 9.07.2014.

53 Will Google buy Sealand?, http://www.sealandnews.com/will-google-buy-sealand_206.html, odczyt $\mathrm{z}$ dn. 12.05.2011.

${ }^{54}$ Zob. Beyond the Law: WikiLeaks to Move Its Servers to International Waters at Sealand, http:// www.news.com.au/technology/beyond-the-law-wikileaks-to-move-its-servers-to-internationalwaters-at-sealand/strory-e6frfro0-1226260305633, odczyt z dn. 9.07.2014. 
adaptacja HM Fort Roughs do celów mieszkalnych i prowadzenia działalności gospodarczej została zakończona w listopadzie 2006 roku.

Pomimo rozszerzenia brytyjskiej strefy wód terytorialnych władze Zjednoczonego Królestwa nadal ignorowały istnienie Księstwa Sealand. Dopiero w 1990 roku Ministerstwo Handlu i Przemysłu w opinii sporządzonej na wniosek amerykańskiego Sądu Administracyjnego Federalnej Komisji Komunikacyjnej wypowiedziało się jednoznacznie na temat sytuacji prawnej HM Fort Roughs. Zainteresowanie platformą ze strony organów wymiaru sprawiedliwości Stanów Zjednoczonych zostało wywołane przez obywatela amerykańskiego Allana Weinera, który w latach 1987-1988 prowadził nielegalną rozgłośnię radiową Radio Newyork International na pokładzie statku MV Sarah pływającego u wybrzeży stanu Nowy York pod banderą Księstwa. „Po zasięgnięciu opinii brytyjskiego ministerstwa [...] sąd uznał, że takie państwo nie istnieje. Platforma była jedynie opuszczoną instalacją wojskową, zatopioną na wodach będących [...] morzem terytorialnym Wielkiej Brytanii. Roy Bates był obywatelem brytyjskim, a instalacja nie została oficjalnie uznana za niepodległe państwo, więc nie mogła rejestrować statków” ${ }^{55}$. Natomiast Zarząd Instalacji Morskich Korony (Marine Estates Department) w piśmie z dnia 16 listopada 2004 roku, skierowanym do rumuńskiego naukowca dr. Erica Gildera z Uniwersytetu w Sibiu, stwierdził, że „platforma jest usytuowana na dnie morskim, którego właścicielem jest Zjednoczone Królestwo [...] zgodnie z Territorial Sea Act 1987. [...] Korona zajmuje się wyłącznie zarządzaniem powierzonego jej obszaru [...], nie roszcząc sobie pretensji do samej wieży [HM Fort Roughs]"56. Formalnie zarząd nad platformą, na podstawie umowy zawartej z Ministerstwem Obrony w 1956 roku, nadal sprawuje korporacja Trinity House. Jednak okoliczność niewykonywania przez nią zobowiązań umownych w okresie ostatnich 40 lat stanowi przesłankę uzasadniającą uznanie umowy za niewiążącą dla stron z mocy desuetudo ${ }^{57}$. Słuszności takiej interpretacji dowodzi również fakt, że Trinity House nie otrzymuje z budżetu Ministerstwa jakichkolwiek środków na prowadzenie prac konserwatorskich ${ }^{58}$. W konsekwencji żaden organ brytyjskiej administracji publicznej nie

55 A. Golicki, Księstwo Sealandu jako dyskusyjny przykład mikropaństwa powstałego na morzu, http://www.gol icki.com/index.php?option=com_content\&task=view\&id=5\&Itemid=1, odczyt $\mathrm{z}$ dn. 9.07.2014.

56 Ibidem.

57 Desuetudo (łac.) - utrata mocy obowiązującej przez niestosowanie.

58 Na podstawie informacji uzyskanych w rozmowie telefonicznej z rzecznikiem prasowym Trinity House Vikki Gilson w dniu 21 października 2010 roku. 
wykonuje obecnie ani de iure, ani nawet de facto zarządu platformą, na której znajduje się Księstwo Sealand. Brak zainteresowania Korony i rządu brytyjskiego sposobem wykorzystania HM Fort Roughs nie jest jednak równoznaczny z uznaniem istnienia sealandzkiej strefy „wód terytorialnych”. Zgodnie bowiem z zasadą wyrażoną w art. 60 ust. 8 Konwencji ONZ o prawie morza z dnia 10 grudnia 1982 roku, ratyfikowanej przez Wielką Brytanię w dniu 25 lipca 1997 roku, znajdujące się w wyłącznej strefie ekonomicznej państwa przybrzeżnego ${ }^{59}$ sztuczne wyspy, instalacje i konstrukcje nie mają statusu wysp, nie posiadają własnego morza terytorialnego, wyłącznej strefy ekonomicznej lub szelfu kontynentalnego. Ponadto $\mathrm{z}$ treści art. 2 tego aktu wynika, że państwa przybrzeżne mają pełną suwerenność nad swoim morzem terytorialnym ${ }^{60}$. Regulacje Konwencji (jako akceptowane przez większość państw na świecie ${ }^{61}$ ) zostały przyjęte przez władze brytyjskie za punkt wyjścia do określenia zakresu swojego władztwa nad $H M$ Fort Roughs. Skoro bowiem platforma nie jest naturalną wyspą i znajduje się na wodach terytorialnych Wielkiej Brytanii, to zamieszkująca ją społeczność nie ma zdolności do wysuwania roszczeń terytorialnych, a tym samym nie może utworzyć samodzielnego podmiotu prawa międzynarodowego.

Natomiast w ocenie Roya Batesa oraz emigracyjnego rządu sealandzkiego proklamowanie Księstwa nastąpiło na terytorium, które nie będąc wykorzystywanym od 1956 roku przez wojsko, organy administracji publicznej oraz osoby prywatne, stanowiło w rzeczywistości res nullis. W treści opinii prawnej sporządzonej dla Rządu Księstwa Sealand na Uchodźstwie w 1978 roku prof. dr Bela Vitanyi z Uniwersytetu w Nijmegen podkreślił, że Wielka Brytania jako sygnatariusz IV Konwencji Genewskiej ONZ o szelfie kontynentalnym z dnia 29 kwietnia 1958 roku $^{62}$ „była zobowiązana do usunięcia opuszczonych lub nieużywanych instalacji [...], a skoro rząd brytyjski dotychczas tego nie zrobił,

59 Wody terytorialne znajdują się w obrębie wyłącznej strefy ekonomicznej. Zob. J. Simonides, Morska strefa ekonomiczna, „Sprawy Międzynarodowe” 1976, nr 12, s. 7-20.

60 Konwencja Narodów Zjednoczonych o prawie morza sporządzona w Montego Bay dnia 10 grudnia 1982 r., „Dziennik Ustaw” 2002, nr 59, poz. 543, art. 60 ust. 8, art. 2 ust. 1 i 3.

61 Do 15 listopada 2010 r. Konwencja została ratyfikowana przez 161 państw oraz Wspólnotę Europejską. Zob. Oceans and Law of the Sea: Chronological List of Ratifications of Accessions and Successions to the Convention and Related Agreements as at 15 November 2010, http://www.un.org/ Depts/los/refer ence_files/chronological_lists_of_ratifications.htm, odczyt z dn. 9.07.2014.

62 Zob. Konwencja o szelfie kontynentalnym sporzadzona w Genewie dnia 29 kwietnia 1958 r., „Dziennik Ustaw” 1964, nr 28, poz. 179. 
to należy się przychylić do zdania, że nie sprawuje już władzy nad platformą" ${ }^{63}$. Bezspornym jest również, że HM Fort Roughs do 1987 roku znajdowała się na wodach międzynarodowych pozostających poza jurysdykcją wymiaru sprawiedliwości i organów administracji Wielkiej Brytanii, o czym może świadczyć treść wyroku Essex Assizes z 1968 roku oraz pisma Home Office do Hansa Fuhra z 1981 roku, a także okoliczność nieingerowania przez organy podległe Koronie i rządowi brytyjskiemu w wewnętrzne sprawy Księstwa. Przyjmując taki punkt widzenia, decyzja Margaret Thatcher o rozszerzeniu brytyjskiej strefy wód terytorialnych w październiku 1987 roku stanowiła pogwałcenie prawa międzynarodowego, ponieważ nie uwzględniała suwerenności Księstwa nad obszarem HM Fort Roughs oraz przylegającym do platformy akwenem morskim.

Istotnym problemem dotyczącym statusu prawnego Księstwa Sealand była (i jest nadal) kwestia uznania przez społeczność międzynarodową. Wprawdzie zgodnie z art. 1 i 3 VII Międzynarodowej Konwencji Amerykańskiej ${ }^{64}$ o prawach i obowiązkach państw z dnia 26 grudnia 1933 roku państwo powinno posiadać stałych mieszkańców, terytorium, rząd oraz „zdolność do wchodzenia w stosunki z innymi państwami [...], a polityczna egzystencja państwa nie jest uzależniona od uznania przez inne państwa"65. Wyrażona w treści Konwencji deklaratywna koncepcja podmiotowości prawnomiędzynarodowej ma jednak tę wadę, że złożone przez podmiot aspirujący do statusu państwa oświadczenie o posiadaniu zdolności uczestniczenia w stosunkach międzynarodowych może zostać odczytane jako niewiarygodne lub nieprawdziwe przez kraje, które już są uczestnikami tych stosunków. W takim przypadku Księstwu Sealand zostałby zagwarantowany nie „pełny i normalny byt polityczny, a raczej nędzna egzystencja na marginesie życia międzynarodowego" ${ }^{66}$. Dopiero uznanie przez społeczność międzynarodową, „wyrażające ideę »kooptacji« i zbiorowej weryfikacji państwowych kwalifikacji podmiotu”67, mogłoby zapewnić HM Fort Roughs autentyczny

63 Legal Opinion about the International Status of the Principality of Sealand rendered by Dr. Bela Vitanyi 1978, http://principality-of-sealand.eu/pdf/vitanyi_legal_opinion.pdf, odczyt z dn. 9.07.2014.

${ }^{64} \mathrm{~W}$ prawie międzynarodowym nie została dotychczas sformułowana definicja państwa, która zostałaby zaakceptowana przez ogół lub większość społeczności międzynarodowej, toteż najczęściej określa się państwo przy pomocy terminu wypracowanego w $1933 \mathrm{r}$. na potrzeby regionalne w ramach VII Międzynarodowej Konwencji Amerykańskiej w Montevideo. Zob. M. Sobczyński, op.cit., s. 23-29.

65 Department of International Law, Convention on the Rights and Duties of States, http://www. oas.org/juridico/english/treaties/a-40.html, odczyt z dn. 9.07.2014.

66 M. Sobczyński, op.cit., s. 50.

67 L. Oppenheim, International Law, London 2006, vol. I, s. 184. 
i niekwestionowany status niezawisłego państwa. Dotychczas jednak żaden suwerenny kraj nie zdecydował się uznać podmiotowości międzynarodowej Księstwa de iure, tj. w formie oficjalnej, bezwarunkowej i nieodwołalnej deklaracji, wyrażającej się wolą nawiązania stosunków dyplomatycznych, konsularnych, politycznych, gospodarczych i kulturalnych ${ }^{68}$.W tej sytuacji rodzina Batesów oraz emigracyjne „władze” sealandzkie uznały, że dostateczną przesłanką uzasadniającą stwierdzenie posiadania przez Księstwo cech państwa jest uznanie de facto wyrażone przez inne kraje poprzez „nawiązanie przez uznawanego i uznającego dwustronnych relacji ekonomicznych, kulturalnych lub innych [...] pomimo braku pewności co do trwałości bytu uznawanego państwa"69. Stanowisko takie potwierdziła opinia prawna sporządzona 5 lutego 1975 roku przez prof. dr. Waltera Meisnera z Uniwersytetu w Erlangen na wniosek Rządu Księstwa Sealand na Uchodźstwie. Autor opinii stwierdził, że Księstwo uzyskało status państwowy w wyniku: „uznawania przez Wielką Brytanię, Francję i Republikę Federalną Niemiec (dyplomatycznych) paszportów sealandzkich, [...] prowadzenia przez ambasadę brytyjską w Bonn korespondencji [...] z przedstawicielami władz Księstwa Sealand w RFN [...], z której wynika, że istnienie Księstwa jest znane władzom brytyjskim i nie wnoszą one wobec tego bytu żadnych protestów"70. Przyjmując ten punkt widzenia, emigracyjny „rząd” sealandzki umieścił na swojej stronie internetowej fragmenty korespondencji z władzami niemieckimi na szczeblu kraju związkowego (z Ministerstwem Sprawiedliwości Nadrenii-Westfalii) oraz federalnym (z Ministerstwem Sprawiedliwości i Biurem Kanclerza RFN), władzami brytyjskimi (Foreign and Commonwealth Office ${ }^{71}$ ) oraz rosyjskimi i amerykańskimi przedstawicielami dyplomatycznym w Niemczech, jako dowód faktycznego uznania podmiotowości prawnomiędzynarodowej Księstwa przez Niemcy, Wielką Brytanię, Rosję i Stany Zjednoczone ${ }^{72}$. Z kolei dla „legalnego rządu" sealandzkiego najistotniejszym wydarzeniem świadczącym o faktycznym uznaniu Księstwa za uczestnika stosunków międzynarodowych były rozmowy

68 J.P. de Andrade Barroso, Uznanie państwa w świetle prawa międzynarodowego, Warszawa 1994, s. 32 .

69 Ibidem, s. 34.

70 Rechtsgutachen über die völkerrechtliche Situation der Principality of Sealand erstattet von Dr. Walter Leisner 1975, http://principality-of-sealand.eu/archiv/s_gutachten_leisner_d.html, odczyt $\mathrm{z}$ dn. 9.07.2014.

71 Foreign and Commonwealth Office to ministerstwo spraw zagranicznych Wielkiej Brytanii.

72 Chancellor Letters, http://principality-of-sealand.eu/hotstuff/kanzlerbriefe_e.html, odczyt z dn. 9.07.2014. 
w sprawie uwolnienia Gernota Putza prowadzone przez pracowników Ambasady Niemieckiej w Londynie bezpośrednio z Royem Batesem. Natomiast prof. Vitanyi jako kluczowy argument przemawiający za posiadaniem przez Księstwo zdolności do nawiązywania stosunków zagranicznych wskazał „zaakceptowanie przez władze sealandzkie [...] zasad wynikających z Karty Narodów Zjednoczonych, a tym samym jurysdykcji Międzynarodowego Trybunału Sprawiedliwości ${ }^{73}$ oraz wprowadzenie do Konstytucji Księstwa podstawowych praw człowieka"74.

Reasumując dotychczasowe rozważania, należy stwierdzić, że Księstwo Sealand nie spełnia wszystkich warunków uznanych przez społeczność międzynarodową za niezbędne do uzyskania statusu suwerennego państwa. Wysoce wątpliwa wydaje się bowiem możliwość zastosowania do HM Fort Roughs zasady res nullis credit primo occupanti, skoro w chwili zajęcia przez Roya Batesa platforma pozostawała pod zarządem korporacji Trinity House, o czym świadczy incydent z maja 1968 roku. Wprawdzie wyrokiem z dnia 25 października 1968 roku Essex Assizes uznał, że HM Fort Roughs nie znajduje się pod jurysdykcją sądów angielskich, ale orzeczenie to dotyczyło jedynie zakresu odpowiedzialności karnej Roya i Michaela Batesów za nielegalne posiadanie broni palnej. Wyrok nie mógł zatem stanowić podstawy do uznania za nieważną umowy zawartej między brytyjskim Ministerstwem Obrony i korporacją Trinity House, nawet gdyby okazało się, że spory wynikające z realizacji tej umowy nie mogą być rozstrzygane przez organy angielskiego wymiaru sprawiedliwości. Stosowana przez rodzinę Batesów i „władze” emigracyjne rozszerzająca interpretacja wyroku z 1968 roku wydaje się zatem bezpodstawna. Naturalną konsekwencją takiego rozumowania jest uznanie, że pozostająca pod zarządem Trinity House platforma nie stanowiła res nullis, toteż jej zajęcie przez Roya Batesa nastąpiło w złej wierze i nie powinno wywoływać skutku w postaci proklamowania Księstwa obejmującego swoim zasięgiem HM Fort Roughs. Brak terytorium jest przesłanką decydującą o nieważności deklaracji „władz” sealandzkich w przedmiocie ustanowienia 3-milowej strefy wód terytorialnych we wrześniu 1967 roku oraz jej rozszerzenia we wrześniu 1987 roku. Wynika z tego, że Wielka Brytania, rozszerzając strefę swoich wód terytorialnych w dniu 1 października 1987 roku, nie dopuściła się naruszenia prawa międzynarodowego, ponieważ 12-milowa strefa brytyjska nie kolidowała ze strefą jakiegokolwiek suwerennego państwa.

73 Statut Międzynarodowego Trybunału Sprawiedliwości stanowi integralną część Karty Narodów Zjednoczonych. Zob. E.J. Omańczyk, op.cit., s. 233.

74 Legal Opinion..., op.cit. 
Nie posiadając własnego terytorium, Księstwo Sealand nie może również mieć stałych mieszkańców. Jednak nawet gdyby kwestię ludności rozpatrywać w oderwaniu od problemu terytorium, to nie ulega wątpliwości, że „obywatele sealandzcy” (nie wyłączając rodziny Batesów) zamieszkują poza granicami $H M$ Fort Roughs, co świadczy o braku stałych mieszkańców na platformie. Tymczasem „współczesne prawo międzynarodowe nie zna pojęcia państwa koczowniczego”75, toteż podmiot pozbawiony terytorium i ludności nie może sobie rościć pretensji do posiadania praw analogicznych do przysługujących suwerennym państwom.

Opierając się na deklaratywnej koncepcji podmiotowości prawnomiędzynarodowej, można uznań, że wystarczającą przesłanką wskazującą na istnienie zdolności uczestniczenia Księstwa Sealand w relacjach międzynarodowych byłoby nawiązanie przez „władze” sealandzkie stosunków z jakimkolwiek uznanym państwem lub organizacją międzynarodową. Ponieważ jednak dotąd zdolność ta nie została pozytywnie zweryfikowana, nadal zachowuje aktualność stwierdzenie zawarte w piśmie Home Office do Hansa Fuhra z 1981 roku, że powody uzasadniające uznanie państwowości HM Fort Roughs nie są znane ani rządowi brytyjskiemu, ani jakiemukolwiek innemu rządowi. Jest bowiem oczywiste, że incydentalny kontakt przedstawicieli Ambasady RFN w Londynie z Royem Batesem w 1978 roku nie miał na celu nawiązania kontaktów dyplomatycznych, lecz został wymuszony specyficzną sytuacją, w jakiej znalazł się obywatel niemiecki. Podobnie nieuzasadnione jest również interpretowanie poruszenia kwestii sealandzkiej w prywatnej korespondencji, prowadzonej między przedstawicielami władz niemieckich i brytyjskich oraz członkami „rządu” Johannesa Siegera, jako wyraz uznania de facto państwowości Księstwa. Skoro zatem społeczność międzynarodowa milcząco odmówiła uznania prawnego i faktycznego Księstwu, to podmiot ten nie posiada w efekcie zdolności prowadzenia własnej polityki zagranicznej. Sytuacji tej nie mogą zmienić jednostronne deklaracje „władz” sealandzkich, ponieważ do powstania stosunku międzynarodowego konieczne jest współdziałanie co najmniej dwóch podmiotów prawa międzynarodowego ${ }^{76}$.

Spośród czterech czynników warunkujących sine qua non istnienie bytu państwowego, według definicji zawartej w treści Konwencji z 1933 roku (akceptowanej przez „legalne” i emigracyjne „władze” sealandzkie), Księstwo Sealand bezspornie spełnia jedynie wymóg posiadania własnego rządu. Poważne wąt-

75 L. Antonowicz, Pojęcie państwa w prawie międzynarodowym, Warszawa 1974, s. 126.

76 Zob. I. Wycichowska, Stosunki międzynarodowe i ich uwarunkowania, [w:] Społeczeństwo i polityka. Podstawy nauk politycznych, red. K.A. Wojtaszczyk, W. Jakubowski, Warszawa 2003, s. 583. 
pliwości dotyczące istnienia terytorium i stałej ludności sealandzkiej oraz brak zdolności w zakresie prowadzenia polityki zagranicznej dyskwalifikuje Księstwo jako nie tylko jako suwerenne państwo, ale jako podmiot prawa międzynarodowego w ogóle. Biorąc jednak pod uwagę obecny sposób wykorzystania $H M$ Fort Roughs oraz plany rodziny Batesów dotyczące sprzedaży praw do platformy, należy przypuszczać, że casus Księstwa Sealand nie doprowadzi do wytworzenia nowej kategorii prawnej. Bardziej prawdopodobne wydaje się stopniowe przekształcenie tego podmiotu w kolejną mikronację ${ }^{77}$, której aktywność będzie się ograniczała do podejmowania działań w warunkach wirtualnych.

${ }^{77}$ Mikronacja lub państwo wirtualne to zorganizowana przez społeczność internetową symulacja państwa w warunkach wirtualnych. Zob. J. Ryan, G. Dunford, S. Sellars, op.cit., s. 4-6. 